\title{
Immunization coverage of children aged 24-35 months in the Islamic Republic of Iran: a national cluster coverage survey
}

Seyed Mohsen Zahraei, ${ }^{1}$ Shahrokh Izadi, ${ }^{2}$ Mohammad Mehdi Gouya, ${ }^{1}$ Seyed Mohammad Hashemi Shahri ${ }^{3}$ and Mahdi Mohammadi ${ }^{4}$

${ }^{1}$ Department of Infectious Diseases, Centre for Communicable Diseases Control, Ministry of Health and Medical Education, Tehran, Islamic Republic of Iran. ${ }^{2}$ Department of Epidemiology, School of Public Health, Isfahan University of Medical Sciences, Isfahan, Islamic Republic of Iran (Correspondence to: S. Izadi: izadish@yahoo.com). ${ }^{3}$ Department of Infectious Diseases, School of Public Medicine, Zahedan University of Medical Sciences, Zahedan, Islamic Republic of Iran. ${ }^{4}$ Department of Biostatistics, Health Promotion Research Centre, School of Public Health, Zahedan University of Medical Sciences, Zahedan, Islamic Republic of Iran.

\begin{abstract}
Background: Although vaccination coverage against a disease is not exactly the same as community immunity against that disease, it is undoubtedly directly related to it and provides an estimate of the coherence and efficacy of community health infrastructure.
\end{abstract}

Aims: To evaluate the vaccination coverage of children throughout the Islamic Republic of Iran in 2019.

Methods: This was a cross-sectional study. A probability proportional to size cluster sampling method was used and the vaccination data of 8682 children aged 24-35 months were collected in the form of 1447 clusters, each comprising six participants. Only valid data, including vaccination card or electronic health files, were used. The results were reported in the form of descriptive tables.

Results: Overall, $97.82 \%$ of Iranian participants (8068 of 8248 ) and $90.32 \%$ of non-Iranian participants (392 of 434 ) had received all essential childhood vaccination by the time of interview. In total, $93.02 \%$ of all participants had presentable vaccination cards, and the immunization history of $535(6.16 \%)$ children was retrieved using their electronic health files. The dropout rate between receiving pentavalent vaccine 1 and pentavalent vaccine 3 was $0.01 \%$. In 29 provinces, vaccination coverage was $\geq 95 \%$. In the other two provinces, the figure was $93.30 \%$.

Conclusion: Immunization coverage of children aged 24-35 months fully complied with eradication/elimination goals of vaccine-preventable diseases. In 2019, measles and rubella elimination was certified in the Islamic Republic of Iran. However, non-Iranian residents with immunization coverage < 95\% constitute a high-risk group for possible outbreaks.

Keywords: vaccination, immunization, coverage, Iran, children.

Citation: Zahraei SM; Izadi S; Gouya MM; Shahri SMH; Mohammadi M. Immunization coverage of children aged $24-35$ months in the Islamic Republic of Iran: a national cluster coverage survey. East Mediterr Health J. 2022;28(2):121-129. https://doi.org/10.26719/emhj.21.059

Received: 21/10/20; accepted: 15/06/21

Copyright (C) World Health Organization (WHO) 2022. Open Access. Some rights reserved. This work is available under the CC BY-NC-SA 3.o IGO license (https://creativecommons.org/licenses/by-nc-sa/3.o/igo)

\section{Introduction}

The Expanded Program on Immunization (EPI) was launched in the Islamic Republic of Iran in 1984. Thanks to national policies and the national immunization plan, vaccine coverage is $>95 \%$. This has played a fundamental role in achieving EPI goals, such as polio eradication and measles elimination. Vaccination coverage is usually monitored continuously based on the data gathered in registries; however, sometimes administrative coverage is calculated using aggregate reported data on the number of doses of each vaccine administered to children in the target age group in a given period $(1,2)$.

According to the National Immunization Program of Iran, the following vaccines are given free of charge to every child. At birth: BCG (Bacillus Calmette-Guérin), hepatitis B, and bOPV zero (bivalent oral polio vaccine containing type 1 and 3 serotypes only); age 2 months: pentavalent 1 (diphtheria, pertussis, tetanus, hepatitis $\mathrm{B}$ and Haemophilus influenzae type b) and bOPV1; age 4 months: pentavalent 2, bOPV2 and inactivated polio vaccine (IPV); age 6 months: pentavalent 3 and bOPV3; age 1 year: MMR1 (measles, mumps and rubella); and age 18 months: MMR2, DTP1 (diphtheria, tetanus and pertussis), and bOPV. One dose of IPV was introduced in the immunization schedule in September 2015; however, it was discontinued in May 2016 because of a global vaccine shortage.

In the Islamic Republic of Iran, a data quality selfassessment survey, conducted in 2017, showed good validity and reliability of routine administrative data (3). However, sometimes the quality of primary recordings, transcriptions, or compilation of data might not be high enough due to possible over- or under-reporting $(4,5)$. Other methods for monitoring the system, such as surveys, have been introduced by the World Health Organization (WHO) to obtain more accurate estimates of immunization coverage $(2,6,7)$.

The last nationwide immunization coverage survey in the Islamic Republic of Iran was conducted in 2013 (8). After about five years, implementation of another survey was justified as a monitoring tool for managers in charge of immunization programmes. The main objective of the 
present study was to provide reliable and valid estimates of the immunization coverage in all subgroups of the population in all 31 provinces.

\section{Methods}

\section{Study methods}

This was a cross-sectional study of vaccination coverage in all 31 provinces of the Islamic Republic of Iran. The main approach was to retrieve data recorded on the vaccination cards of children who had been invited to participate in the study. For children whose vaccination cards were not accessible, the required data were retrieved from a newly developed health information system known as the Integrated Comprehensive Health Information System (ICHIS). ICHIS is a special health infrastructure system where the detailed vaccination history of all residents is recorded.

A questionnaire specially designed for the study was used for data gathering during interview in the home or doorstep of each participant. The questionnaire contained 18 questions and a table was used to record and collect data. In addition to the data on vaccines received by the children, other data were collected during a short interview with their parents at their homes. These data included the child's birth rank, parents' level of education, reasons for possible delays in the implementation of the child's vaccination programme (only in cases where delay was registered in the child's vaccination card), and the interviewees' opinions about the benefits of vaccination. Interviews were conducted by interviewers adept in local languages.

\section{Pilot study}

The pilot phase of the study was conducted between 7 and 21 January 2019. During this phase, 180 children (aged 24-30 months) were sampled in 28 clusters in urban and rural areas within Tehran and Sistan-va-Baluchestan Provinces, and their parents or guardians were interviewed. Based on the findings of this phase, the study methods were revised and the questionnaire was improved and finalized.

\section{Study sample}

Based on the latest National Population and Housing Census, conducted in 2016, the total Iranian population should be nearly 80 million (9). This population is not distributed homogeneously throughout the country. There are provinces and large municipal areas (such as Tehran, Shiraz, Mashhad, etc.) with highly dense populations, and provinces with highly scattered populations and low-density areas (e.g. Yazd Province). To select the sample, the probability proportional to size cluster sampling method was used (10). The mean family size is about 3.4 for rural areas and 3.3 for urban areas; therefore, the size of a cluster was decided to be six children, that is, the number of participants that were expected to be found during a working day in a given neighbourhood. To estimate coverage of $\sim 95 \%$, with precision of $1.0 \%$ and $99 \%$ confidence interval (CI) $(\alpha=0.01)$, and an intracluster correlation coefficient (ICC) of 0.35 (i.e., the design effect equal to 2.75), the required sample size was calculated at 8682 children, equal to 1447 clusters of size $6(7,10)$.

\section{Sampling methods}

An instructional pamphlet was prepared for district and provincial supervisors as well as for interviewers. The pamphlet contained details about methods of sampling and interviewing in different field situations. A shortened version of the same instructions, containing the most important points, was printed on the second page of the questionnaire. To answer unforeseen questions and situations, the telephone numbers of two contact persons (district and university supervisors) for each district were included, and the staff and health workers could call them at any time. All the staff and health workers involved in implementing the study were in contact with one another and with the principal investigator through a WhatsApp group. This WhatsApp group provided a platform for the exchange of information, questions, and experiences of the co-workers at various levels (from the front-line interviewers up to the ministry staff).

\section{Quality assurance}

The field phase of the study in all provinces began on 15 June 2019 and ended by 25 July 2019. In addition to the above-mentioned instruction pamphlet, briefing sessions were held for all the health workers and interviewers involved in the study. In each district, at the end of the day's work, the supervisor responsible for overseeing the study reviewed all questionnaires delivered for the day.

\section{Data bank and analysis}

To minimize errors at the data entry stage, a double data entry method was used. The data were transferred from the paper questionnaires to a data bank created in Microsoft Access using an intelligent questionnaire capable of checking for and preventing a series of data entry errors. The data were entered into two separate computer data banks twice. For the first time, the data were entered into the databases created in the Access programme in the universities implementing the project; and for the second time, they were entered into the databases created in the Access programme in the headquarters of the Centre for Disease Control of the Ministry of Health. The data were analysed using Stata version 11.2 statistical software. For analysis of the data, where applicable, the $95 \% \mathrm{CI}$ was reported along with the mean and standard deviation.

\section{Ethics}

The Ethics Committee on Medical Research of Zahedan University of Medical Sciences reviewed and approved the study protocol (the Ethics Certification Code: IR.ZAUMS.REC.1397.329). Participation in the study was voluntary, and those who accepted the invitation were only requested to take part in the interview and present their children's vaccination cards, without being subjected to any other request or procedure, invasive or noninvasive. 


\section{Results}

Table 1 and Supplementary Table 1 show the general profile of the study sample. The age composition of the whole sample was within the defined range (24-35 months); however, 41 participants (36 Iranians and 5 non-Iranians) were younger than 1.95 years (712 days) and 82 (70 Iranians and 12 non-Iranians) were older than 3.05 years (1112 days). Supplementary Table 2 shows the age distribution of the sample by nationality and Supplementary Table 3 shows their sex distribution by nationality and province.

\section{Non-Iranian participants}

The Iranian participants comprised $95.0 \%$ of the sample ( $n$ $=8248)$, and the non-Iranian participants the remaining $5.0 \%(n=434)$. Except for 10 children from Iraq and Pakistan, the remaining $424(4.88 \%)$ non-Iranian participants were from Afghanistan. More than $95 \%$ of the non-Iranian participants were residents of 10 provinces, with Tehran having the largest share (46.31\%). Supplementary Table 4 shows the provincial distribution of these participants. In addition to these 10 provinces, there were seven other provinces with a total share of $<2 \%$.

\section{Vaccination cards and ICHIS}

Supplementary Table 5 shows vaccination card ownership by nationality and residential area (urban vs rural). Overall, $93.02 \%$ of participants had presentable vaccination cards. This proportion was highest among rural residents (95.92\%). Also, $91.47 \%$ of the non-Iranian participants had vaccination cards. In total, 569 (6.90\%) Iranian participants and 37 (8.53\%) non-Iranian participants could not present their vaccination cards or any other documented history of their children's immunization status. There were 535 of these children, 516 Iranians $(6.26 \%$ of the Iranian participants) and 19 non-Iranians (4.38\% of the non-Iranian participants), who had documented records in the ICHIS, from where their vaccination history was retrieved.

\section{Role of private sector in immunization coverage}

Sixty-one (0.70\%) participants were immunized mostly by private sector health service providers, and only five of these participants were non-Iranians. Among the Iranians, 32 (57.14\%) participants were from Tehran Province (Supplementary Table 6).

\section{Vaccination coverage}

Overall, 8068 of 8248 (97.8\%, 95\% CI: 97.5-98.1\%) Iranian participants and 392 of 434 (90.3\%, 95\% CI: 87.5-93.1\%) non-Iranian participants had received all essential childhood vaccines by the time of the interview. Supplementary Table 7 shows the vaccination coverage by province. Table 2 shows the vaccination coverage that, according to the National Vaccination Programme, must be received before the first birthday by residential area (urban vs rural) and nationality. Supplementary Tables 8 and 9 show the coverage for each of the vaccines to be received in the first two years of life, regardless of whether they were received late or on time, and Supplementary Table 10 shows the age distribution of the Iranian participants at the time of administration of each vaccine. Table 3 shows the distribution of the sample by province, the share of the ICHIS in the completion of data, and nationality. The other parts of the questionnaire were completed with interview at the participants' homes. The contribution of the ICHIS to the completion of data varied widely among the provinces. There have even been provinces (i.e. Yazd and Ilam) with no use of the ICHIS, while others (e.g. Isfahan and Tehran) had $>10 \%$ of their vaccination data

\begin{tabular}{|c|c|c|c|}
\hline & $\begin{array}{c}\text { Male } \\
\text { No. } \\
\text { (\% of row) } \\
\text { (\% of column) }\end{array}$ & $\begin{array}{c}\text { Female } \\
\text { No. } \\
\text { (\% of row) } \\
\text { (\% of column) }\end{array}$ & $\mathbf{P}$ \\
\hline All participants & $\begin{array}{c}4630 \\
(53.33) \\
(100)\end{array}$ & $\begin{array}{c}4052 \\
(46.67) \\
(100)\end{array}$ & - \\
\hline Iranian participants & $\begin{array}{c}4384 \\
(53.15) \\
(94.69)\end{array}$ & $\begin{array}{c}3864 \\
(46.85) \\
(95.36)\end{array}$ & - \\
\hline Non-Iranian participants & $\begin{array}{c}246 \\
(56.68) \\
(5.31)\end{array}$ & $\begin{array}{c}188 \\
(43.32) \\
(4.64)\end{array}$ & - \\
\hline Participants with full vaccination schedule & $\begin{array}{c}4487 \\
(53.04) \\
(96.91)\end{array}$ & $\begin{array}{c}3973 \\
(46.96) \\
(98.05)\end{array}$ & $0.001^{c}$ \\
\hline Iranian participants with full vaccination schedule & $\begin{array}{c}4272 \\
(52.95) \\
(97.45)^{\mathrm{a}}\end{array}$ & $\begin{array}{c}3796 \\
(47.05) \\
(98.24)^{\mathrm{a}}\end{array}$ & $0.015^{c}$ \\
\hline $\begin{array}{l}\text { Non-Iranian participants with full vaccination } \\
\text { schedule }\end{array}$ & $\begin{array}{c}215 \\
(54.85) \\
(87.40)^{b}\end{array}$ & $\begin{array}{c}177 \\
(45.15) \\
(94.15)^{b}\end{array}$ & $0.021^{c}$ \\
\hline
\end{tabular}

${ }^{a}$ Percentage from only Iranian participants. ${ }^{b}$ Percentage from non-Iranian participants. ${ }^{~}$ Two-sided exact test. 


\begin{tabular}{|c|c|c|c|c|}
\hline Vaccine & $\begin{array}{l}\text { Iranian urban } \\
\text { residents } \\
(\% \text { of } 6093)\end{array}$ & $\begin{array}{l}\text { Iranian rural } \\
\text { residents } \\
\text { (\% of 2155) }\end{array}$ & $\begin{array}{l}\text { Non-Iranians } \\
(\% \text { of } 434)\end{array}$ & $\begin{array}{c}\text { Total } \\
\text { (\% of 8682) }\end{array}$ \\
\hline BCG & $\begin{array}{l}6005 \\
(98.56)\end{array}$ & $\begin{array}{c}2151 \\
(99.81)\end{array}$ & $\begin{array}{c}408 \\
(94.01)\end{array}$ & $\begin{array}{c}8564 \\
(98.64)\end{array}$ \\
\hline At-birth OPV & $\begin{array}{l}6000 \\
(98.47)\end{array}$ & $\begin{array}{c}2148 \\
(99.68)\end{array}$ & $\begin{array}{c}404 \\
(93.09)\end{array}$ & $\begin{array}{c}8552 \\
(98.50)\end{array}$ \\
\hline At-birth hepatitis B vaccine & $\begin{array}{c}6003 \\
(98.52)\end{array}$ & $\begin{array}{c}2149 \\
(99.72)\end{array}$ & $\begin{array}{c}407 \\
(93.78)\end{array}$ & $\begin{array}{c}8559 \\
(98.58)\end{array}$ \\
\hline 1st OPV (scheduled for age 2 months) & $\begin{array}{l}6028 \\
(98.93)\end{array}$ & $\begin{array}{c}2152 \\
(99.86)\end{array}$ & $\begin{array}{c}405 \\
(93.32)\end{array}$ & $\begin{array}{c}8585 \\
(98.88)\end{array}$ \\
\hline 1st Pentavalent vaccine (scheduled for age 2 months) & $\begin{array}{l}6027 \\
(98.92)\end{array}$ & $\begin{array}{c}2152 \\
(99.86)\end{array}$ & $\begin{array}{c}405 \\
(93.32)\end{array}$ & $\begin{array}{l}8584 \\
(98.87)\end{array}$ \\
\hline 2nd OPV (scheduled for age 4 months) & $\begin{array}{l}6020 \\
(98.80)\end{array}$ & $\begin{array}{c}2151 \\
(99.81)\end{array}$ & $\begin{array}{c}408 \\
(94.01)\end{array}$ & $\begin{array}{l}8579 \\
(98.81)\end{array}$ \\
\hline 2nd Pentavalent vaccine (scheduled for age 4 months) & $\begin{array}{c}6019 \\
(98.79)\end{array}$ & $\begin{array}{c}2151 \\
(99.81)\end{array}$ & $\begin{array}{c}407 \\
(93.78)\end{array}$ & $\begin{array}{c}8577 \\
(98.79)\end{array}$ \\
\hline 3rd OPV (scheduled for age 2 months) & $\begin{array}{c}6007 \\
(98.59)\end{array}$ & $\begin{array}{c}2143 \\
(99.44)\end{array}$ & $\begin{array}{c}403 \\
(92.86)\end{array}$ & $\begin{array}{l}8553 \\
(98.51)\end{array}$ \\
\hline 3rd Pentavalent vaccine (scheduled for age 4 months) & $\begin{array}{c}6007 \\
(98.59)\end{array}$ & $\begin{array}{c}2143 \\
(99.44)\end{array}$ & $\begin{array}{c}403 \\
(92.86)\end{array}$ & $\begin{array}{l}8553 \\
(98.51)\end{array}$ \\
\hline Children who have received all vaccines before age 1 year & $\begin{array}{l}5956 \\
(97.75)\end{array}$ & $\begin{array}{c}2133 \\
(98.98)\end{array}$ & $\begin{array}{c}394 \\
(90.78)\end{array}$ & $\begin{array}{l}8483 \\
(97.71)\end{array}$ \\
\hline
\end{tabular}

BCG = Bacillus Calmette-Guérin; $O P V=$ oral polio vaccine.

coming from the ICHIS (Supplementary Table 5). Table 4 shows two vaccination coverage indicators: the dropout rate between receiving the 1st and 3rd pentavalent vaccines by residential area (urban vs rural) and the dropout rate between receiving the BCG and MMR1 vaccines. Although the reported vaccination coverage in the first 24 hours was far from the national goals, it is one of the best among developing countries $(11,12)$.

\section{Discussion}

The total vaccination coverage in children aged 24-35 months in the Islamic Republic of Iran, as well as the coverage for each of the vaccines under review can be assessed as very high and appropriate, that is, > 95\% (Tables 1 and 3). The percentage of children who had received their vaccines on time was acceptable in all population subgroups (Iranians vs non-Iranians and urban vs rural residents) (Table 2). These findings are consistent with the reports of routine administrative data management systems as well as with reports of the WHO and United Nation's Children's Fund (UNICEF) on the coverage of vaccination in the Islamic Republic of Iran over the past decade $(13,14)$.

Supplementary Table 11 shows the distribution of the age of administration of at-birth hepatitis B vaccine to Iranians by province. Supplementary Table 12 shows the completeness of vaccination for hepatitis B by nationality and residential area (of Iranians). Since perinatal or early postnatal transmission is recognized as the most important source of chronic hepatitis B infection, the WHO has set a goal of $100 \%$ coverage, that is, vaccination of all infants ideally within the first 24 hours of life $(15,16)$.
According to this guideline, if the vaccine is not given within the first 24 hours, it is still possible to prevent the disease for up to one week, although the effectiveness will decrease over time $(15,17)$. A total of $90.41 \%$ of all participants had received at-birth hepatitis $B$ vaccine during the first 24 hours of life, and $96.0 \%$ had received it by the end of the first week (Supplementary Table 12). Although the results for the end of the first week are favourable, more monitoring, emphasis and training should be applied to achieve the national goal of $>95 \%$ during the first 24 hours of life. Hepatitis B immunization strategy among infants and other high-risk groups has resulted in a significant decrease in hepatitis B surface antigen carrier status in the community from $>2.9 \%$ before 2010 to $<1.3 \%$ after 2010 (18).

Table 1 shows the distribution of the sample by sex. Among Iranian participants, the sex difference in vaccination coverage was < $1 \%(97.45 \%$ male vs $98.24 \%$ female), and the coverage for both sexes was $>95 \%$. However, in statistical analysis (Tables 1 and 2), the difference between the two sexes was significant, which was undoubtedly due to the excessive test power resulting from the large sample size. Among the non-Iranian participants, there was a difference of nearly $7 \%$ between the vaccination coverage of male and female participants $(87.40 \%$ vs $94.15 \%)$. According to the WHO report on the vaccination programme in Afghanistan, depending on the security situation and health infrastructure, the vaccination coverage of Pentavalent 3 in different areas was estimated at $71-90 \%(19)$.

One of the most important strengths of the present study was that all percentages were calculated and reported based on filed documents (not memory and 


\begin{tabular}{|c|c|c|c|c|c|c|}
\hline Provinces & $\begin{array}{c}\text { No. of } \\
\text { Iranian } \\
\text { participants }\end{array}$ & $\begin{array}{l}\text { No. of fully } \\
\text { immunized } \\
\text { Iranian } \\
\text { participants } \\
(\%)\end{array}$ & $\begin{array}{c}\text { No. of } \\
\text { records } \\
\text { retrieved } \\
\text { from ICHIS } \\
(\%)\end{array}$ & $\begin{array}{l}\text { No. of non- } \\
\text { Iranian } \\
\text { participants }\end{array}$ & $\begin{array}{c}\text { No. of fully } \\
\text { immunized } \\
\text { non-Iranian } \\
\text { participants } \\
(\%)\end{array}$ & $\begin{array}{c}\text { No. of } \\
\text { records } \\
\text { retrieved } \\
\text { from ICHIS } \\
(\%)\end{array}$ \\
\hline Alborz & 280 & 277 (98.9) & $14(5.0)$ & 26 & $26(100.0)$ & $\mathrm{o}(0.0)$ \\
\hline Ardebil & 138 & $137(99.3)$ & $13(9.4)$ & 3 & $2(66.7)$ & $\mathrm{o}(0.0)$ \\
\hline West Azerbaijan & 336 & $333(99.1)$ & $4(1.2)$ & - & - & - \\
\hline East Azerbaijan & 438 & $434(99.1)$ & $19(4 \cdot 3)$ & - & - & - \\
\hline Bushehr & 111 & $110(99.1)$ & $4(3.6)$ & - & - & - \\
\hline Chaharmahal and Bakhtiari & 96 & $96(100.0)$ & $8(8.3)$ & - & - & - \\
\hline Isfahan & 519 & $519(100.0)$ & $66(12.7)$ & 57 & $57(100.0)$ & $2(2.5)$ \\
\hline Fars & 494 & $490(99.2)$ & $16(3.2)$ & 22 & $22(100.0)$ & $0(0.0)$ \\
\hline Guilan & 306 & $302(98.7)$ & $3(1.0)$ & - & - & - \\
\hline Golestan & 194 & $190(97.9)$ & $17(8.8)$ & 4 & $2(50.0)$ & $1(25.0)$ \\
\hline Kohgiluyeh and Boyer-Ahmad & 66 & $66(100.0)$ & $9(13.6)$ & - & - & - \\
\hline Hamedan & 192 & $190(99.0)$ & $4(2.1)$ & - & - & - \\
\hline Hormozgan & 177 & $172(97.2)$ & $6(3.4)$ & 3 & $3(100.0)$ & $0(0.0)$ \\
\hline Ilam & 60 & $59(98.3)$ & $0(0.0)$ & - & - & - \\
\hline Kerman & 304 & $298(98.0)$ & $21(6.9)$ & 32 & $31(96.9)$ & $0(0.0)$ \\
\hline Kermanshah & 210 & $206(98.1)$ & $3(1.4)$ & - & - & - \\
\hline Khuzestan & 462 & $454(98.3)$ & $30(6.5)$ & - & - & - \\
\hline Southern Khorasan & 76 & $72(95.0)$ & $7(9.2)$ & 2 & $2(100.0)$ & \\
\hline Khorasan Razavi & 677 & $675(99.7)$ & $46(6.8)$ & 19 & $19(100.0)$ & $3(15.8)$ \\
\hline Northern Khorasan & 90 & $87(96.7)$ & $2(2.2)$ & - & - & - \\
\hline Kurdistan & 168 & $167(99.4)$ & $2(1.2)$ & - & - & - \\
\hline Lorestan & 180 & $179(99.4)$ & $3(1.7)$ & - & - & - \\
\hline Markazi & 159 & $159(100.0)$ & $8(5.0)$ & 3 & $2(66.7)$ & $1(33.3)$ \\
\hline Mazandaran & 387 & $383(99.0)$ & $33(8.5)$ & 3 & $2(66.7)$ & $\mathrm{o}(0.0)$ \\
\hline Qazvin & 139 & $138(99.3)$ & $11(7.9)$ & 5 & $5(100.0)$ & $\mathrm{o}(0.0)$ \\
\hline Qom & 119 & $111(93.3)$ & $11(9.2)$ & 19 & $15(79.0)$ & $2(10.5)$ \\
\hline Sistan-va-Baluchestan & 233 & $221(95.0)$ & $4(1.7)$ & 19 & $13(68.4)$ & $0(0.0)$ \\
\hline Semnan & 65 & $65(100.0)$ & $3(4.6)$ & 13 & $12(92.3)$ & $1(7.7)$ \\
\hline Tehran & 1341 & $1251(93.3)$ & $147(11.0)$ & 201 & $176(87.6)$ & $9(4.5)$ \\
\hline Yazd & 117 & $113(96.6)$ & $0(0.0)$ & 3 & $3(100.0)$ & $0(0.0)$ \\
\hline Zanjan & 114 & $114(100.0)$ & $2(1.8)$ & - & - & - \\
\hline Total & 8248 & 8068 (97.8) & $516(6.3)$ & 434 & $392(90.3)$ & $19(4.4)$ \\
\hline
\end{tabular}

ICHIS = Integrated Comprehensive Health Information System.

recall); that is, they were based on the information recorded in the vaccination cards and ICHIS. In a similar study conducted in $2013, \sim 80 \%$ of the estimates were based on information recorded on children's vaccination cards, and the remainder were calculated and reported based on maternal memory recall (8). The latest recommendations and guidelines of the WHO emphasize that vaccine coverage studies must be based on written and credible documents and maternal memory must not be used (7).

According to the findings reported in Table 4, the dropout rates for Pentavalent 1 to Pentavalent 3 and BCG to MMR1 were practically equal to zero, and judging by these two indicators, it might be said that the adequacy of immunization services to achieve the goals of the immunization programme is acceptable $(20,21)$. To achieve the goal of eliminating measles and rubella, the vaccine coverage of the first and second doses should be $\geq 95 \%(22,23)$. In 2019, measles and rubella elimination in the Islamic Republic of Iran was certified by the WHO Regional Office for the Eastern Mediterranean, which indicates high vaccine coverage and quality in the country (24).

Even though our results indicate that the Iranian vaccination programme has been successful in achieving the goals set by WHO, it should be noted that due to the gap that usually exists between vaccination coverage and 


\begin{tabular}{lccc}
\hline Table 4 Coverage indices by residential area (urban vs rural) & & \\
& $\begin{array}{c}\text { For urban residential } \\
\text { areas (only Iranians) }\end{array}$ & $\begin{array}{c}\text { For rural residential } \\
\text { areas (only Iranians) }\end{array}$ & $\begin{array}{c}\text { Total } \\
\text { (only Iranians) } \\
\%\end{array}$ \\
Pentavalent 1 - pentavalent 3 dropout rate & 0.00 & 0.00 & 0.01 \\
BCG - MMR1 dropout rate & 0.00 & 0.00 & 0.00 \\
\hline
\end{tabular}

Study of the immunization coverage of children aged 24-35 months in the Islamic Republic of Iran, spring and summer 2019. BCG = Bacillus Calmette-Guérin; MMR1 = measles, mumps and rubella vaccine 1 .

seroconversion rate, the vaccination coverage cannot be interpreted as the percentages of the protected.

Our results show that the private sector has a minor role in providing vaccination services, which seems to be due to the extensive coverage and good development of the public health system. In India, depending on the economic situation of different states, the percentage of private sector participation in vaccination coverage varies. For example, for $\mathrm{DTP}_{3}$, it varies from $\sim 6.1 \%$ in affluent states to $<1 \%$ in less-privileged states (25). In Pakistan, however, private sector participation in vaccination coverage does not exceed 3\% (26). In some countries, nongovernmental organizations (NGOs) play an important role in vaccination. For example, almost all of Afghanistan's vaccination coverage, $\sim 40 \%$ of Cambodia's, and $\sim 20 \%$ of Bangladesh's in rural areas is provided by NGOs (26). The role of NGOs in providing health services in the Islamic Republic of Iran is generally low.

As mentioned earlier in this study, Afghan participants accounted for $4.88 \%$ of the total $5.0 \%$ of nonIranian participants. Supplementary Tables 3 and 5 show the distribution of these participants in different parts of the Islamic Republic of Iran. In recent years, the percentage of Afghan participants has changed significantly from one study to another. For example, in a large-scale study of vaccination coverage conducted across the Islamic Republic of Iran in 2013, Afghans accounted for $11.9 \%$ of the participants. In another seroprevalence study conducted in the southeastern provinces of the Islamic Republic of Iran, non-Iranian participants accounted for only $1.4 \%$ of the total (27). It must be acknowledged that some of these differences were due to population movement and the areas in which the studies were conducted. The small number of participants taken from the non-Iranian population in our study means that we did not obtain a good estimate of their vaccination coverage, and it would be better to conduct a separate study with a suitable sample size to accurately evaluate the vaccination coverage of the nonIranian population.

In this study, we used the probability proportional to size cluster sampling method, recommended by WHO, to evaluate vaccination coverage. The most important feature of this method is that larger population centres will have a better chance of being present in the sample, and as a result, smaller and inaccessible population centres may not be well represented. Therefore, although the results of this study may provide a good assessment of vaccination coverage in the age groups covered, they may not be fully generalized to smaller population centres and remote populations.

\section{Conclusion}

The present study shows that, in most parts of the Islamic Republic of Iran, vaccination coverage by the national vaccination programme is good and acceptable. Taking into account the coverage rate and drop-out indicators, the Iranian vaccination programme has performed excellently, which has been confirmed by reports from WHO and UNICEF and by the WHO's certification of measles elimination in 2019. To achieve the goal of eliminating hepatitis $\mathrm{B}$, efforts and monitoring should be strengthened. Another point worth mentioning here is that although physicians in the private sector play a role in encouraging parents for immunization, their role in providing vaccination services in the Islamic Republic of Iran is trivial. The non-Iranian population with immunization coverage $<95 \%$ are considered a high-risk group for possible future outbreaks.

\section{Acknowledgement}

The authors would like to thank all provincial and district health managers and related health facilities for their kind cooperation and support. We appreciate the tireless efforts of Ms Fatemeh Abdoli Yaghini, who coordinated the project and field implementation. The authors wish to express their gratitude to Dr Ali Beikian, the faculty member of English Language Department of Chabahar Maritime University, for language editing and proofreading of the English text of this article.

Funding: This work was supported by the World Health Organization, Tehran Office, (WHO Registration 2018/863108-1).

Competing interests: None declared. 


\section{Couverture vaccinale des enfants âgés de 24 à 35 mois en République islamique d'Iran : enquête nationale de couverture par sondage en grappes}

\section{Résumé}

Contexte : La couverture vaccinale contre une maladie ne correspond pas tout à fait à l'immunité de la communauté contre cette maladie, mais elle y est sans aucun doute directement liée et fournit une estimation de la cohérence et de l'efficacité de l'infrastructure de santé communautaire.

Objectifs : Évaluer la couverture vaccinale des enfants dans l'ensemble de la République islamique d'Iran en 2019.

Méthodes: Il s'agissait d'une étude transversale. Une méthode d'échantillonnage en grappes avec probabilité proportionnelle à la taille a été utilisée et les données de vaccination de 8682 enfants âgés de 24 à 35 mois ont été recueillies sous forme de 1447 grappes composées chacune de six participants. Seules des données valides, notamment les carnets de vaccination ou les dossiers médicaux électroniques, ont été utilisées. Les résultats ont été présentés sous forme de tableaux descriptifs.

Résultats: Dans l'ensemble, $97,82 \%$ des participants iraniens (8068 sur 8248) et 90,32\% des participants non iraniens (392 sur 434) avaient reçu tous les vaccins infantiles nécessaires au moment de l'entretien. Au total, $93,02 \%$ de tous les participants avaient des carnets de vaccination consultables, et l'historique de vaccination de 535 enfants (6,16\%) a été récupéré par le biais de leurs dossiers médicaux électroniques. Le taux d'abandon entre la première et la troisième doses du vaccin pentavalent était de 0,01\%. Dans 29 provinces, la couverture vaccinale était supérieure ou égale à $95 \%$. Dans les deux autres provinces, ce taux était de 93,30\%.

Conclusion: La couverture vaccinale des enfants âgés de 24 à 35 mois était pleinement conforme aux objectifs d'éradication/élimination des maladies évitables par la vaccination. En 2019, l'élimination de la rougeole et de la rubéole a été certifiée en République islamique d'Iran. Cependant, les résidents non iraniens ayant une couverture vaccinale inférieure à $95 \%$ constituent un groupe à haut risque en cas de flambée épidémique.

$$
\text { للتغطية تطعيم الأطفال الذين تتراوح أعلارهم بين } 24 \text { و } 35 \text { شهرًا في جمهورية إيران الإسلامية: مسح وطني عنقودي }
$$

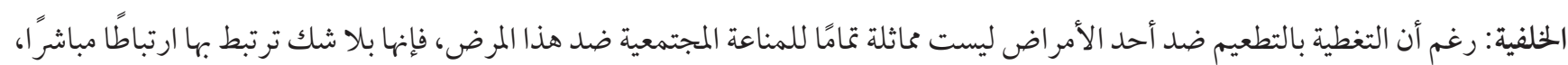

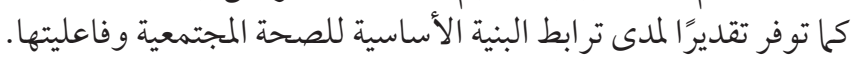
الأهداف: هدفت هذه الدراسة إلى تقييم التغطية بتطعيم الأطفال في جميع أنحاء جمهورية إيران الإسلامية في عام 1920.

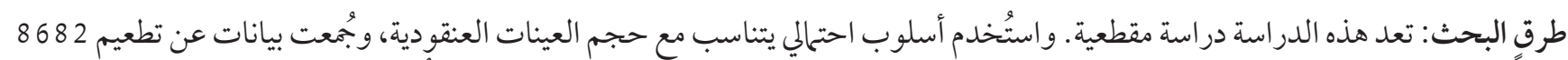

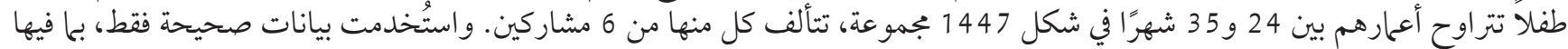

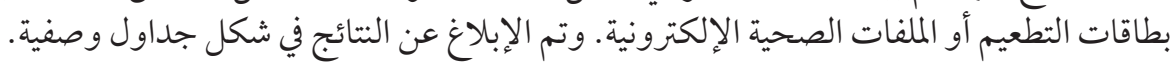

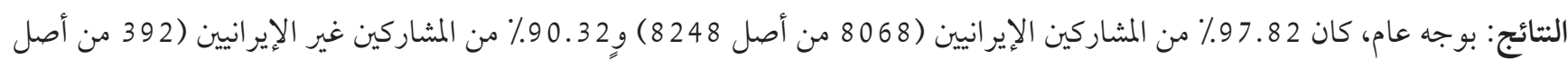

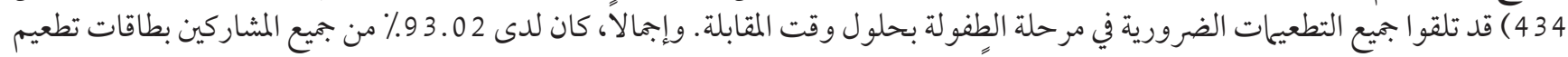

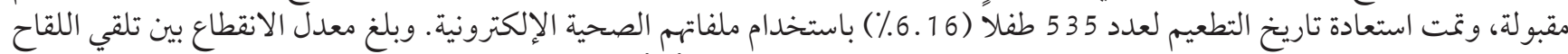

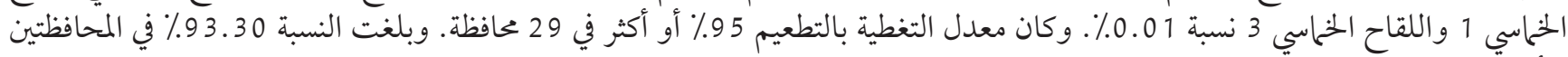
الأخرين.

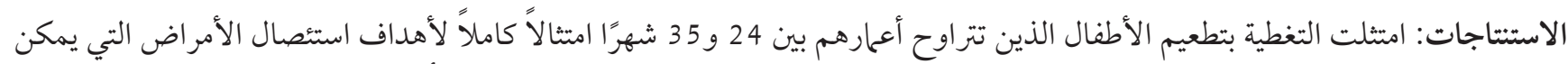

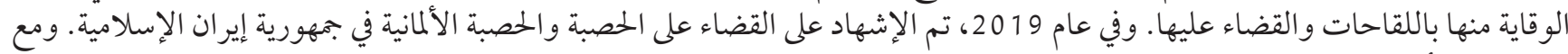

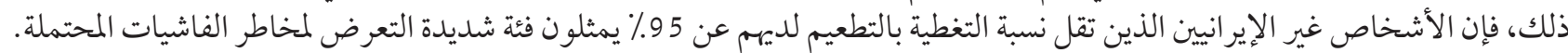

\section{References}

1. Imran H, Raja D, Grassly NC, Wadood MZ, Safdar RM, O’Reilly KM. Routine immunization in Pakistan: comparison of multiple data sources and identification of factors associated with vaccination. Int Health. 2018 Mar 1;10(2):84-91. https://doi.org/10.1093/ inthealth/ihxo67 PMID:29432552 
2. Cutts FT, Claquin P, Danovaro-Holliday MC, Rhoda DA. Monitoring vaccination coverage: defining the role of surveys. Vaccine. 2016 Jul 29;34(35):4103-9. https://doi.org/10.1016/j.vaccine.2016.06.053 PMID:27349841

3. Karami M, Khazaei S, Babaei A, Yaghini FA, Gouya MM, Zahraei SM. Accuracy and quality of immunization data in Iran: findings from data quality self-assessment survey in 2017. BMC Health Serv Res. 2019 Jun 11;19(1):371. https://doi.org/10.1186/s12913019-4188-9 PMID:31185983

4. Lim SS, Stein DB, Charrow A, Murray CJ. Tracking progress towards universal childhood immunisation and the impact of global initiatives: a systematic analysis of three-dose diphtheria, tetanus, and pertussis immunisation coverage. Lancet. 2008 Dec 13;372(9655):2031-46. https://doi.org/10.1016/So140-6736(08)61869-3 PMID:19070738

5. Bosch-Capblanch X, Ronveaux O, Doyle V, Remedios V, Bchir A. Accuracy and quality of immunization information systems in forty-one low income countries. Trop Med Int Health. 2009 Jan;14(1):2-10. https://doi.org/10.1111/j.1365-3156.2008.02181.x PMID:19152556

6. Burton A, Monasch R, Lautenbach B, Gacic-Dobo M, Neill M, Karimov R, et al. WHO and UNICEF estimates of national infant immunization coverage: methods and processes. Bull World Health Organ. 2009 Jul;87(7):535-41. https://doi.org/10.2471/ blt.08.053819 PMID:19649368

7. World Health Organization vaccination coverage cluster surveys: reference manual. Geneva: World Health Organization; 2018 (https://apps.who.int/iris/handle/10665/272820, accessed 27 August 2021).

8. Zahraei SM, Eshrati B, Gouya MM, Mohammadbeigi A, Kamran A. Is there still an immunity gap in high-level national immunization coverage, Iran? Arch Iranian Med. 2014 Oct;17(10):698-701. PMID:25305770

9. Census 2016 - general results [website]. Statistical Center of Iran; 2016 (https://www.amar.org.ir/english/Population-and-Housi ing-Censuses/Census-2016-General-Results, accessed 27 August 2021).

10. Bennett S, Woods T, Liyanage WM, Smith DL. A simplified general method for cluster-sample surveys of health in developing countries. World Health Stat Q. 1991;44(3):98-106. PMID:1949887

11. Allison RD, Patel MK, Tohme RA. Hepatitis B vaccine birth dose coverage correlates worldwide with rates of institutional deliveries and skilled attendance at birth. Vaccine. 2017 Jul 24;35(33):4094-8. https://doi.org/10.1016/j.vaccine.2017.06.051 PMID:28668571

12. Choconta-Piraquive LA, De la Hoz-Restrepo F, Sarmiento-Limas CA. Compliance with birth dose of Hepatitis B vaccine in high endemic and hard to reach areas in the Colombian amazon: results from a vaccination survey. BMC Health Serv Res. 2016 Jul 21;16:293. https://doi.org/10.1186/s12913-016-1542-z PMID:27443313

13. Immunization 2019. New York: United Nation's Children's Fund [website] (https://data.unicef.org/topic/child-health/immunizai tion/, accessed 27 August 2021).

14. WHO vaccine-preventable diseases: monitoring system. 2019 global summary. Geneva: World Health Organization; 2020 [website] (https://apps.who.int/immunization_monitoring/globalsummary/countries?countrycriteria\%5Bcouny try\%5D\%5\%5D=IRN\&commit=OK, accessed 27 August 2021).

15. Hepatitis B vaccines: WHO position paper - July 2017. Releve Epidemiologique Hebdomadaire. 2017 Jan 7;92(27):369-92.

16. Schillie S, Vellozzi C, Reingold A, Harris A, Haber P, Ward JW, et al. Prevention of hepatitis B virus infection in the United States: recommendations of the Advisory Committee on Immunization Practices. MMWR Recomm Rep. 2018 Jan 12;67(1):1-31. https:// doi.org/10.15585/mmwr.rr6701a1 PMID:29939980

17. World Health Organization. Hepatitis B vaccines: WHO position paper, July 2017 - recommendations. Vaccine. 2019 Jan 7;37(2):223-5. https://doi.org/10.1016/j.vaccine.2017.07.046 PMID:28743487

18. Salehi-Vaziri M, Sadeghi F, Almasi Hashiani A, Gholami Fesharaki M, Alavian SM. Hepatitis B virus infection in the general population of Iran: an updated systematic review and meta-analysis. Hepat Mon. 2016 Apr 26;16(4):e35577. https://doi.org/10.5812/ hepatmon.35577 PMID:27257428

19. Afghanistan. Expanded Programme on Immunization (EPI). EPI Review Report 2017. Cairo: World Health Organization Regional Office for the Eastern Mediterranean (http://www.emro.who.int/afg/programmes/epi.html, accessed 27 August 2021).

20. Baguune B, Ndago JA, Adokiya MN. Immunization dropout rate and data quality among children 12-23 months of age in Ghana. Arch Public Health. 2017 Apr 17;75:18. https://doi.org/10.1186/s13690-017-0186-8 PMID:28428878

21. Foege W. The power of immunization. League table: the DTP3 coverage measure. In: The Progress of Nations 2000. New York: UNICEF; 2000: 22-4 (https://www.unicef.org/media/85576/file/Progress-For-Nations-2000.pdf, accessed 27 August 2021).

22. World Health Organization. Measles vaccines: WHO position paper - April 2017. Vaccine. 2019 Jan 7;37(2):219-22. https://doi. org/10.1016/j.vaccine.2017.07.066 PMID:28760612

23. Global measles and rubella strategic plan: 2012-2020. Geneva: World Health Organization; 2012.

24. Namaki S, Gouya MM, Zahraei SM, Khalili N, Sobhani H, Akbari ME. The elimination of measles in Iran. Lancet Glob health. 2020 Feb;8(2):e173-4. https://doi.org/10.1016/S2214-109X(20)30002-4 PMID:31981549

25. Sharma A, Kaplan WA, Chokshi M, Zodpey SP. Role of the private sector in vaccination service delivery in India: evidence from private-sector vaccine sales data, 2009-12. Health Policy Plan. 2016 Sep;31(7):884-96. https://doi.org/10.1093/heapol/czwoo8 PMID:26976803 
26. Levin A, Kaddar M. Role of the private sector in the provision of immunization services in low- and middle-income countries. Health Policy Plan. 2011 Jul;26 Suppl 1:i4-12. https://doi.org/10.1093/heapol/czro37 PMID:21729916

27. Izadi S, Zahraei S, Mokhtari-Azad T. Seroprevalence of antibodies to measles and rubella eight months after a vaccination campaign in the southeast of Iran. Hum Vaccin Immunother. 2018 Jun 3;14(6):1412-6. https://doi.org/10.1080/21645515.2018.1436920 PMID:29420120 